\title{
PELATIHAN TATA KELOLA MEDIA PEMBELAJARAN MULTI MEDIA BERBASIS COMPUTER BASED INTRUCTION UNTUK MENINGKATKAN KUALITAS PENGAJARAN GURU DI SMK AKP GALANG
}

\author{
Yuda Perwira, Paska Marto Hasugian, Endra A.P Marpaung \\ STMIK Pelita Nusantara, Indonesia \\ yudaperwira25@gmail.com
}

\begin{abstract}
Improving the quality of learning by several factors, namely a comfortable room, qualified human resources, the involvement of the media in learning and the willingness of students to develop, the highlight of the PKM team is human resources in this case are teachers. The teacher is one of the objects that cannot be accessed directly from the process, but some of the prisoners who appear are that most of the teachers put forward conventional principles, namely learning that involves blackboard media and textbooks in the learning process, this has an impact on prolonged boredom and boredom because The TIM provides assistance to teachers on the management of multimedia-based learning media. Learning media that will be developed using several applications and will be combined into one application package, namely the Adobe Flash CS application. Adobe Flash CS with its version is one of the most popular and most commonly used parts of animation production today. This program allows users to create various animation applications ranging from animated images (cartoons), interactive animations, games, company profiles, presentations, video clips, web animations, and other animation applications according to user needs. In addition to presenting a variety of attractive images and animations, Adobe Flash CS can also spoil students with the advantages of effects that can help teachers explain subject matter, as well as games and questions to test students' understanding. As a reference for the content of the learning media which will be based on the CBI (Computer Based Intruction)
\end{abstract}

Keywords: Learning Media, MultiMedia, CBI.

\begin{abstract}
Abstrak
Peningkatan kualitas pembelajaran dipengaruhi oleh beberapa faktor yaitu ruangan yang nyaman, sdm yang mumpuni, pelibatan media didalam pembelajaran serta adanya kemauan dari siswasiswa untuk berkembang, yang menjadi sorotan tim PKM adalah SDM dalam hal ini adalah guru. Guru adalah salah satu objek yang tidak dapat dipisahkan dari proses pengajaran yaitu yang menyampaikan materi secara langsung, namun beberapa kendala yang muncul adalah sebagian besar guru masih mengedepankan prinsip konvensioanl yaitu pembelajaran yang hanya melibatkan media papan tulis dan buku ajar dalam proses pembelajaran hal ini berdampak terhadap kejenuhan dan kebosanan yang berkepanjangan oleh karena itu TIM melakukan pendampingan kepada Guru-guru tentang tata kelola media pembelajaran berbasis multimedia. Media Pembelajaan yang akan dikembangkan dengan menggunakan beberapa aplikasi dan akan digabungkan menjadi satu paket aplikasi yaitu aplikasi adobe flash CS. Adobe Flash CS dengan versinya adalah salah satu bagian dari produksi animasi yang sangat populer dan paling banyak digunakan saat ini. Program ini memungkinkan penggunanya untuk membuat berbagai aplikasi animasi mulai dari animasi gambar (kartun), animasi interaktif, permainan, company profile, presentasi, video clip, animasi web, dan aplikasi animasi lainnya sesuai kebutuhan pengguna. Selain menyajikan tampilan gambar dan berbagai macam animasi yang menarik, Adobe Flash CS juga dapat memanjakan siswa dengan kelebihan efek suara yang dapat membantu guru dalam menjelaskan materi pelajaran, juga games dan soal-soal untuk menguji pemahaman siswa. Sebagai acuan isi dari media pembelajaran yang akan dikembangkan berfokus terhadap model pembelajaran berbasis CBI (Computer Based Intruction).
\end{abstract}

Kata Kunci: media pembelajaran, multimedia, CBI. 


\section{Pendahuluan}

Perkembangan teknologi komputer sangat berkembang dan telah merambah terhadap beberapa instansi baik pemerintahan, dunia industri dan tentunya dunia pendidikan. Kaum intelektual yang memahami konsep perkembangan teknolog telah berhasil mengembangkan beberapa perangkat yang dapat meningkatkan produktifitas dan efektifitas dari suatu perkerjaan sesuai dengan bidangnya. Perkembangan teknologi tersebut telah membuat para pengguna semakin dimudahkan dalam melaksanakan kegiatan masing - masing, seperti halnya dalam dunia bisnis sangat berkembang startup market place yang dapat menunjang peningkatan proses peningkatan penjualan yang dilakukan secara online yaitu tokopedia, lazada dan yang lainnya, untuk dunia transportasi yang sangat berkembang adalah gojek dan grab. [1] pada tahun 2019 untuk dunia pendidikan nonformal telah dikembangkan suatu aplikasi ruang guru yang menggantikan les konvensioanal. Dan ynag menjadi sorotan dalam PKM ini adalah pendidikan formal dimana proses pendidikan masih melibatkan tatap muku sebagai proses penyampaian materi. Pendidikan adalah sesuatu yang universal dan berlangsung terus tak terputus dari generasi ke generasi di manapun di dunia ini. Upaya memanusiakan manusia melalui pendidikan itu diselenggarakan sesuai dengan pandangan hidup dan latar belakang sosial setiap masyarakat Menurut Fuad dalam bukunya pendidikan adalah aktivitas dan usaha manusia untuk meningkatkan kepribadiannya dengan jalan membina potensi-potensi pribadinya, yaitu rohani (pikir, karsa, rasa, cipta dan budi nurani). Pendidikan juga berarti lembaga yang bertanggungjawab menetapkan cita-cita (tujuan) pendidikan, isi, sistem, dan organisasi pendidikan. Lembaga-lembaga ini meliputi keluarga, sekolah dan masyarakat. Pendidikan, seperti sifat sasarannya yaitu manusia, mengandung banyak aspek dan sifatnya sangat kompleks. Sebagai proses transformasi budaya, pendidikan diartikan sebagai kegiatan pewarisan budaya dari generasi satu ke genari yang lain. Sebagai proses pembentukan pribadi, pendidikan diartikan sebagai suatu kegiatan yang sistematis dan sistemik terarah kepada terbentuknya kepribadian peserta didik, yang menjadi tujuan utama pengelolaan proses pendidikan yaitu terjadinya proses belajar dan pengalaman belajar. Sebab berkembangnya tingkah laku peserta didik sebagai tujuan belajar hanya dimungkinkan oleh adanya pengalaman belajar yang optimal itu. Kegiatan mendidik diri setiap saat sepanjang hidup itu selalu merupakan kebutuhan terlepas dari hasilnya. Juga bukan sematamata sebagai bekal untuk kehidupan di masa mendatang. Dengan kata lain, pendidikan itu merupakan bagian integral dari hidup itu sendiri, dalam menjalankan kegiatan tersebut perlu adanya suatu pengembangan media pembelajaran.[2], [3]

Media pembelajaran merupakan salah satu komponen pembelajaran yang mempunyai peranan penting dalam proses pendidikan. Pemanfaatan media seharusnya merupakan bagian yang harus mendapat perhatian dari pada pengembang termasuk guru-guru saat ini dalam setiap kegiatan pembelajaran. Oleh karena itu seorang guru selayaknya harus memhami dan perlu mempelajari bagaimana menetapkan media pembelajaran agar dapat mengefektifkan pencapaian tujuan pembelajaran dalam proses belajar mengajar. Pada kenyataannya media pembelajaran masih sering terabaikan dengan berbagai alasan, antara lain: terbatasnya waktu untuk membuat persiapan mengajar, sulit mencari media yang tepat, tidak tersedianya biaya, dan lain-lain. Hal ini 
sebenarnya tidak perlu terjadi jika setiap guru telah mempunyai pengetahuan dan ketrampilan mengenai media pembelajaran. Keberhasilan pembelajaran sangat dipengaruhi kelengkapan media yang digunakan. Serangkaian media yang terdiri lebih dari satu media dan digunakan bersamaan disebut multimedia. mengungkapkan semakin bervariasi media yang digunakan, maka pesan atau materi pembelajaran akan semakin optimal diterima peserta didik. Hal ini karena keragaman modalitas belajar peserta didik, ada yang modalitas belajarnya cenderung visual, audio, atau kinestetik. Penggabungan berbagai jenis media inilah yang melatarbelakangi terbentuknya pembelajaran multimedia. Multimedia secara umum menurut Turban dalam Suyanto [4] adalah kombinasi dari paling sedikit dua media input atau output dari data, media ini dapat berupa audio (suara, musik), animasi, video, teks, grafik, dan gambar. Multimedia dalam konteks komputer menurut Hofstetter dalam Niken dan Dany (2010) merupakan pemanfaatan komputer untuk membuat dan menggunakan teks, grafik, audio, video, dengan menggunakan alat yang memungkinkan pemakai berinteraksi, berkreasi, dan berkomunikasi. Multimedia menurut Niken dan Dany terbagi menjadi dua kategori, yaitu kategori linier dan interaktif. Dapat disimpulkan bahwa multimedia adalah perpaduan berbagai media berupa teks, gambar, grafik, sound, animasi, video, interaksi, dan lain-lain yang telah dikemas ke dalam bentuk file digital untuk menyampaikan informasi atau pesan kepada publik. Iwan Binanto [5] menyebutkan beberapa bidang yang dapat menggunakan multimedia, di antaranya bisnis, sekolah, rumah, tempat umum, dan virtual reality.

Model pembelajaran yang disandingkan dalam tata kelola media pembelajaran adalah Computer Based Instruction (CBI) merupakan istilah yang digunakan untuk kegiatan pembelajaran yang menggunakan komputer dalam proses belajar mengajarnya. CBI merupakan istilah umum untuk segala kegiatan belajar yang menggunakan komputer, baik sebagian maupun keseluruhan Pembelajaran berbasis komputer didalam kelas pada hakekatnya tidak dapat berdiri sendiri. Dibutuhkan kerjasama diantara setiap pihak didalam kelas.

Walaupun didalam CBI ini komputer memegang peranan vokal, namun posisi guru tidak dapat digantikan sepenuhnya. Peran guru yang pada konsep pembelajaran tradisional bersifat sebagai mediator dan pusat pembelajaran, pada konsep CBI guru lebih berperan sebagai organisator dan fasilitator pembelajaran. [6]-[8]

Berdasarkan observasi yang dilakukan pada beberapa sekolah yang ada dilingkungan Dinas pendidikan Kabupatan Deliserdang Khususnya pada kecamatan Galang dengan jumlah SMK sebanyak 6 sekolah baik negeri ataupun swasta dengan jumlah guru yang beragam sesuai dengan kebutuhan pembelajaran, berdasararkan analisi situasi dipilih 3 sekolah yang mewakili beberapa sekolah dengan permasalahan yang berbeda, beberapa kondisi terhadap sekolah mulai kelengkapan data pembelajaran, ketersediaan sarana dan prasarana serta proses pelibatan media pembelajaran dan juga kendalakendala yang dihadapi, sehingga adanya kesepakatan untuk melakukan suatu pendampingan dalam tata kelola media pembelajaran berbasis multimedia denganm pelibatan suatu model yaitu CBI (Computer Based Instruction) namun dengan melakukan pemdampingan Tata Kelola Media Pembelajaran, permasalahan dapat diselesaikan 
dengan baik dan berkelanjutan, sekolah dan kondisi yang ada saat ini berdasarkan analisis situasi dan sekaligus menjadi mitra adalah

SMK AKP Galang (Jl. Perjuangan, Link. VII, Galang, Kabupaten Deli Serdang, Sumatera Utara 20585) Berdasarkan kunjungan yang dilakukan dan berdasarkan penjelasan dari kepala sekolah bahwa guru-guru yang mengajar masih mengedepankan pengajaran konvensional dan memanfaatkan buku menjadi sarana utama, suasana kelas digambarkan berikut ini :

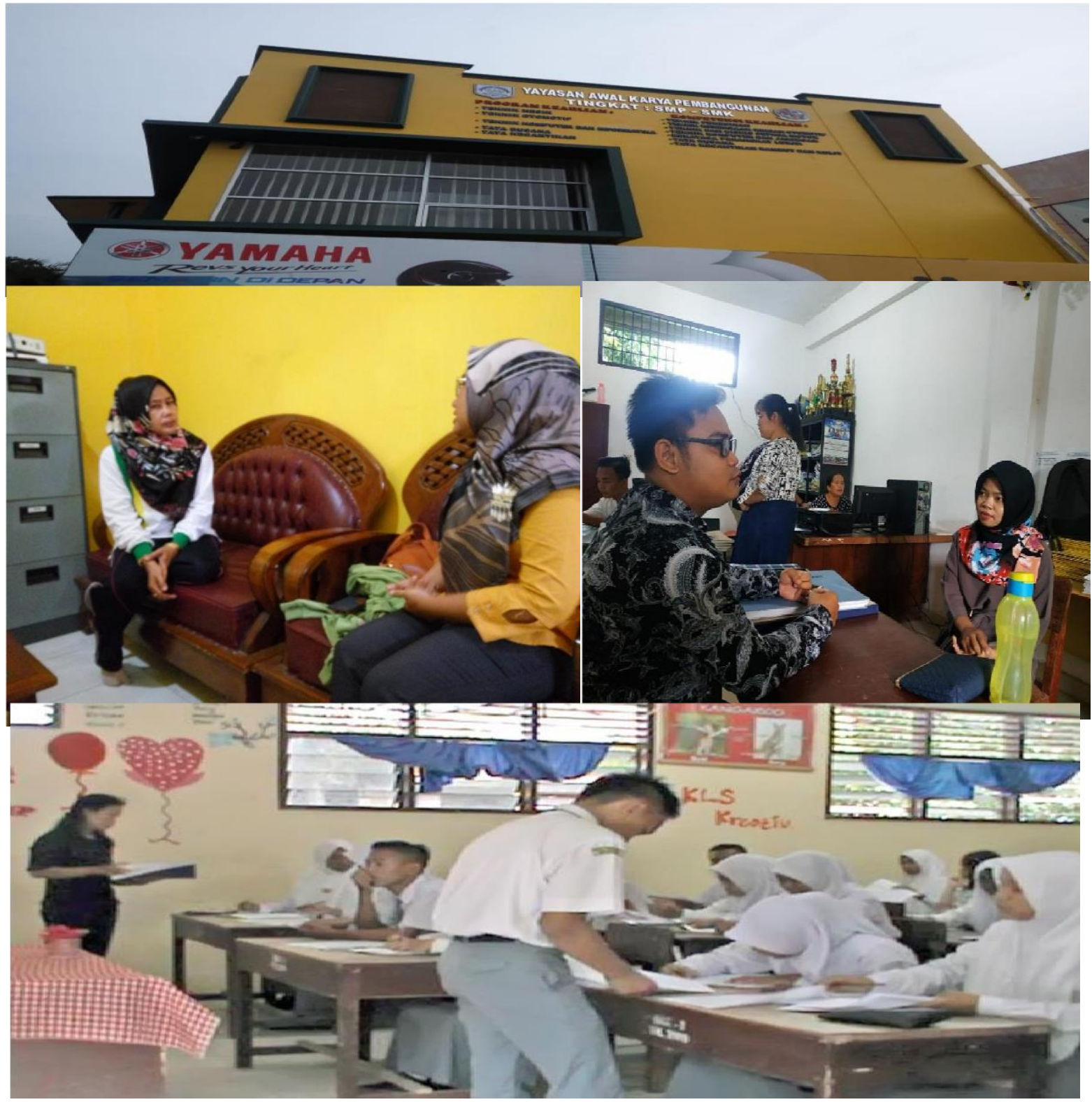

Gambar 1. Tempat PKM dan Kunjungan TIM

Berdasarkan urian tersebut tim PKM ingin memberikan pendampingan dalam pengembangan menggunakan beberapa aplikasi dan akan digabungkan menjadi satu paket aplikasi yaitu aplikasi adobe flash CS dengan pelibatan model pembelajaran CBI. Adobe Flash dengan versinya adalah salah satu program animasi yang sangat populer dan paling banyak digunakan saat ini. Program ini memungkinkan penggunanya untuk membuat berbagai aplikasi animasi mulai dari animasi gambar (kartun), animasi interaktif, 
permainan (game), company profile, presentasi, video clip, animasi web, dan aplikasi animasi lainnya sesuai kebutuhan pengguna. Selain menyajikan tampilan gambar dan berbagai macam animasi yang menarik, Adobe Flash juga memanjakan siswa dengan kelebihan efek suara yang dapat membantu guru dalam menjelaskan materi pelajaran, juga games dan soal-soal untuk menguji pemahaman siswa. [9] Media ini tentu akan menjadi sebuah alternatif sekaligus solusi yang menyenangkan sehingga siswa tidak bosan ketika mengikuti pelajaran dikelas. Model pendampingan yang dilakukan mulai dari tahapan persiapan yaitu kebutuhan apa yang akan dilengkapi untuk proses pengembangan aplikasi pembelajaran, dilanjutkan dengan penggunaan aplikasi adobe flash dasar yaitu pengenalan tools pada, dilanjutkan dengan proses pemanfaatan tools serta membuat proyek aplikasi pembelajaran. Urgensi dalam PKM ini adalah dengan adanya kemampuan guru- guru dalam pembuatan media pembelajaran dengan melibatkan model Pembelajaran komputer diharapkan akan pemicu minat siswa untuk lebih bersemangat dalam mengikuti pelajaran, dan pada akhirnya akan meningkatkan kualitas pembelajaran secara keseluruhan, serta peningkatan kualitas proses pembelajaran.

\section{Metode}

Dalam melaksanakan kegiatan PKM dengan mengikut beberapa prosedur mulai dari proses analisis situasi sampai dengan penutupan pelaksanan, untuk memperjelas diuraikan pada proses berikut ini :

1. Observasi dan Pembuatan Proposal

Pada tahapan ini sudah terlaksana dengan baik yaitu tim Melakukan kunjungan kebeberapa sekolah yang ada dikecamatan Galang dan memastikan permasalahan yang ada dan menghasilkan suatu kesepakatan yaitu proses pendampingan dalam tata kelola media pembelajaran berbasis komputer, Setelah kegaitan observasi dilakukan maka dilanjutkan pada proses pembuatan proposal.

2. Persiapan

Tahapan persiapan adalah tahapan pembagian tugas secara internal antara anggota TIM, dalam kesempatan ini tim merumuskan secara konseptual dan job description dan mempersiapkan form yang dibutuhkan dalam kegiatan seperti halnya presensi kehadiran para peserta materi yang akan disampaikan dan pada tahapan ini dipersiapkan form untuk penerimaan peserta dari sekolah yang lain.

3. Pelaksanan

Tahapan ini adalah proses pelaksanaan kegiatan PKM dengan mengikuti beberapa tahapan sesuai dengan permasalah nya telah didefenisikan. a. Penyajian Materi Pembelajaran Konvensional

Pada tahapan ini tim menjelaskan konsep pembelajaran konvensional dengan menjabarkan apa yang menjadi kekurangan dan kelibihan dari konsep tersebut

b. Penyajian Materi Model Pembelajaran Berbasis Komputer

Pada tahapan ini tim menjelaskan bagiamana prosedur media pembelajaran berbasis komputer dan apa yang menjadi kelebihan dari media tersebut.

c. Penyajian Materi Model Pembelajaran CBI (Computer Base Instruction) 
Pada tahapan ini dilakukan persentasi tentang model pembelajaran berbasis komputer yaitu CBI (Computer Base Instruction) dengan kelebihan - kelebihan nya.

4. Praktek

Tahapan ini merupakan praktek langsung dengan beberapa acuan a. Pengenalan Aplikasi

Pada tahapan ini tim menjelaskan tentang aplikasi yang digunakan serta memberikan penejalasan fungsi dan dan manfaat tools yang ada pada aplikasi Adobe Flash. b. Praktek Sederhana

Tahapan ini adalah tahapan peraltihan dengan memberikan contoh-contoh sederhana seperti halnya pembentukan garis, proses cropping dan yang laiinya seperti pada tabel berikut ini :

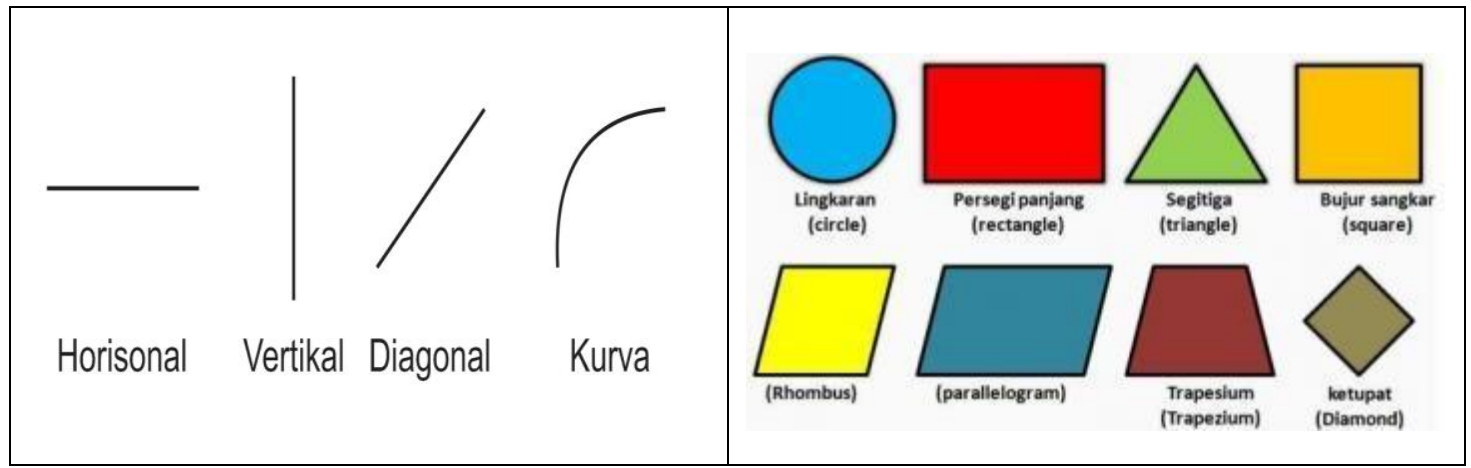

Gambar 2. Tahapan Pembentukan Garis dan Objek

c. Praktek Penggabungan Objek

Pada tahapan ini dilakukan proses penggabungan objek tunggal menjadi objek utuh yang memiliki makna dan dan dapat dikembangkan menjadi bagian dari aplikasi pembelajaran.

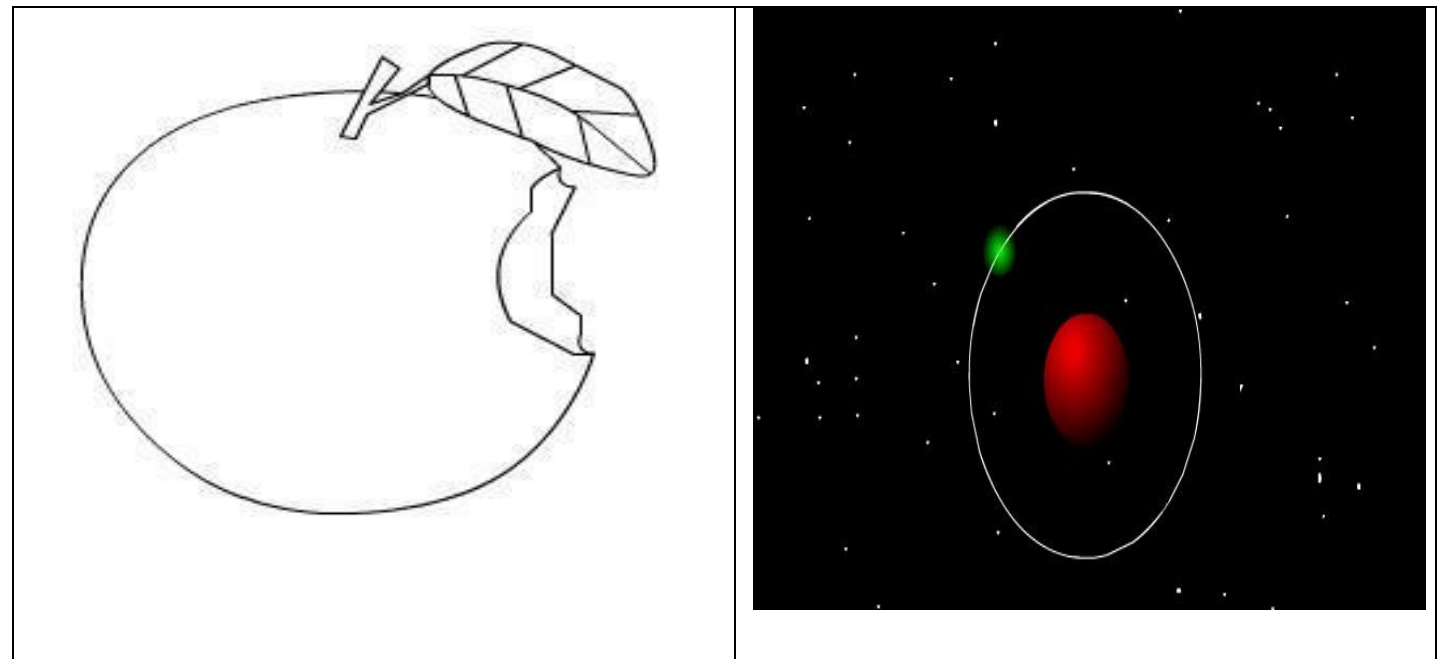

Gambar 3. Penggabungan Objek

d. Praktek Pembuatan Aplikai Pembelajaran

Pada tahapan ini adalah tahapan pembuatan media sesuai dengan bidang studi masing - masing. Seperti contoh dibawah ini : 


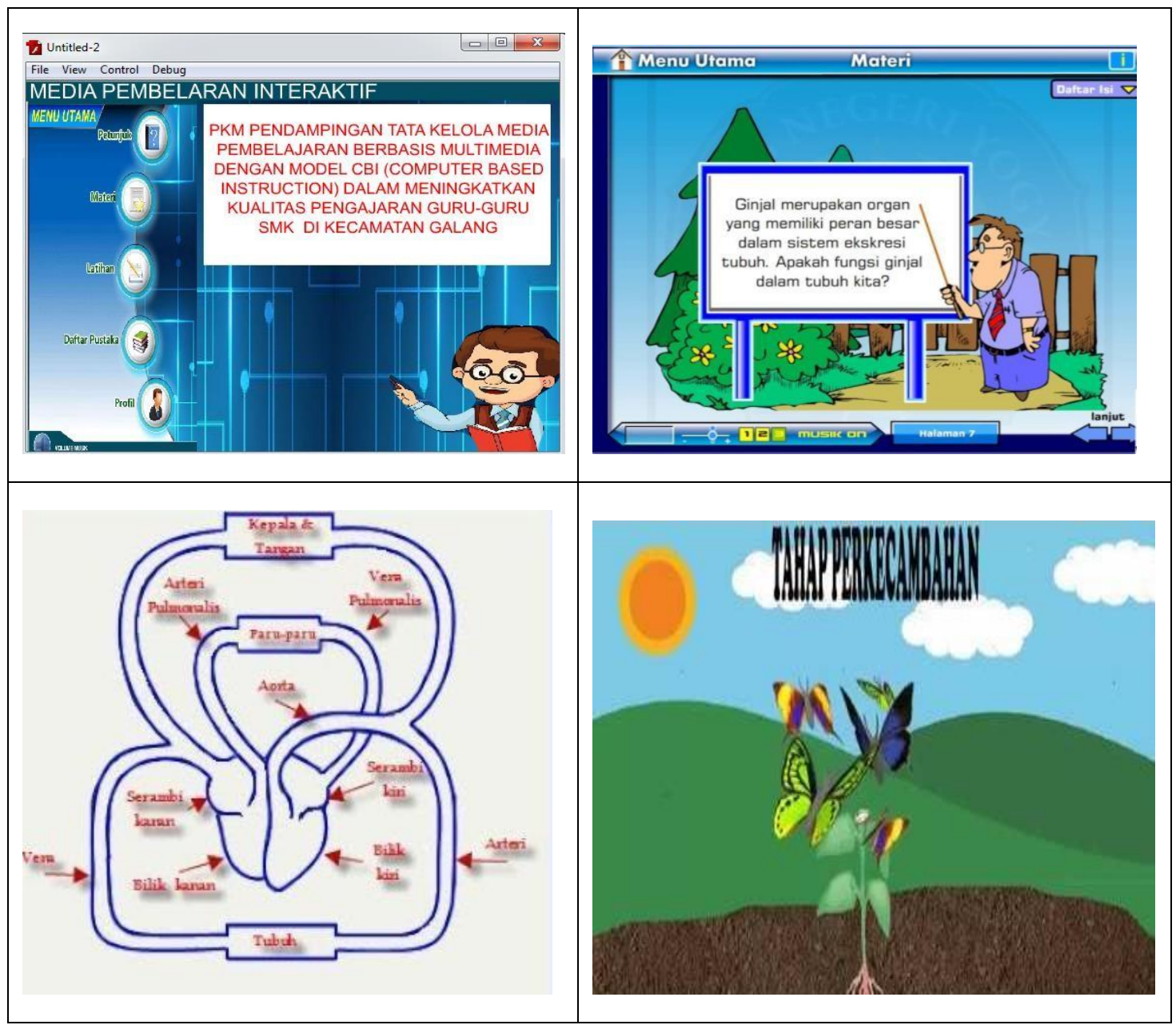

Gambar 4. Pembuatan aplikasi pembelajaran

5. Evaluasi dan Penyempurnaan Aplikasi

Pada tahapan ini akan dilakukan evaluasi terhadap awal tes yang dilakukan dengan tes akhir untuk memastikan efektifitas dari kegaitan dan pendampingan yang dilakukan dan dilakukan penyempurnaan aplikasi sesuai dengan model yang diterapkan.

6. Penutupan dan Pembuatan laporan PKM

Di akhir kegiatan peserta dan Tim melakukan refleksi hasil pelatihan dan para peserta juga memberikan evaluasi akan pelatihan ini. Peserta mendapatkan koreksi dan evaluasi secara langsung terkait hasil karya mereka dan tahapan akhir TIM melakukan penyusunan laporan sesuai dengan aturan dan ketentuan yang telah dilakukan.

\section{Hasil dan Pembahasan}

\section{Realisasi Kegiatan}

Bentuk kegiatan dari pengabdian kepada masyarakat ini adalah dengan cara praktik dan presentase langsung dengan guru-guru SMK AKP Galang selama 3 hari dimana ada sesi ceramah praktik diskusi, Tanya jawab serta pengujian kemampuan untuk mengukur keberhasilan guru-guru dalam mengikuti pelatihan. Dalam melaksanakan kegiatan PKM dengan mengikut beberapa prosedur mulai dari proses analisis situasi sampai dengan penutupan pelaksanan, untuk memperjelas diuraikan pada proses berikut ini : 
Pelaksanan Tahapan ini adalah proses pelaksanaan kegiatan PKM dengan mengikuti beberapa tahapan sesuai dengan permasalah nya telah didefenisikan.

2. Presentasi

a. Penyajian Materi Pembelajaran Konvensional

Pada tahapan ini tim menjelaskan konsep pembelajaran konvensional dengan menjabarkan apa yang menjadi kekurangan dan kelibihan dari konsep tersebut

b. Penyajian Materi Model Pembelajaran Berbasis Komputer

Pada tahapan ini tim menjelaskan bagiamana prosedur media pembelajaran berbasis komputer dan apa yang menjadi kelebihan dari media tersebut.

c. Penyajian Materi Model Pembelajaran CBI (Computer Base Instruction)

Pada tahapan ini dilakukan persentasi tentang model pembelajaran berbasis komputer yaitu CBI (Computer Base Instruction) dengan kelebihan kelebihan nya.

\section{Praktek}

Tahapan ini merupakan praktek langsung dengan beberapa acuan yaitu pengenalan aplikasi dan praktek menggunakan aplikasi
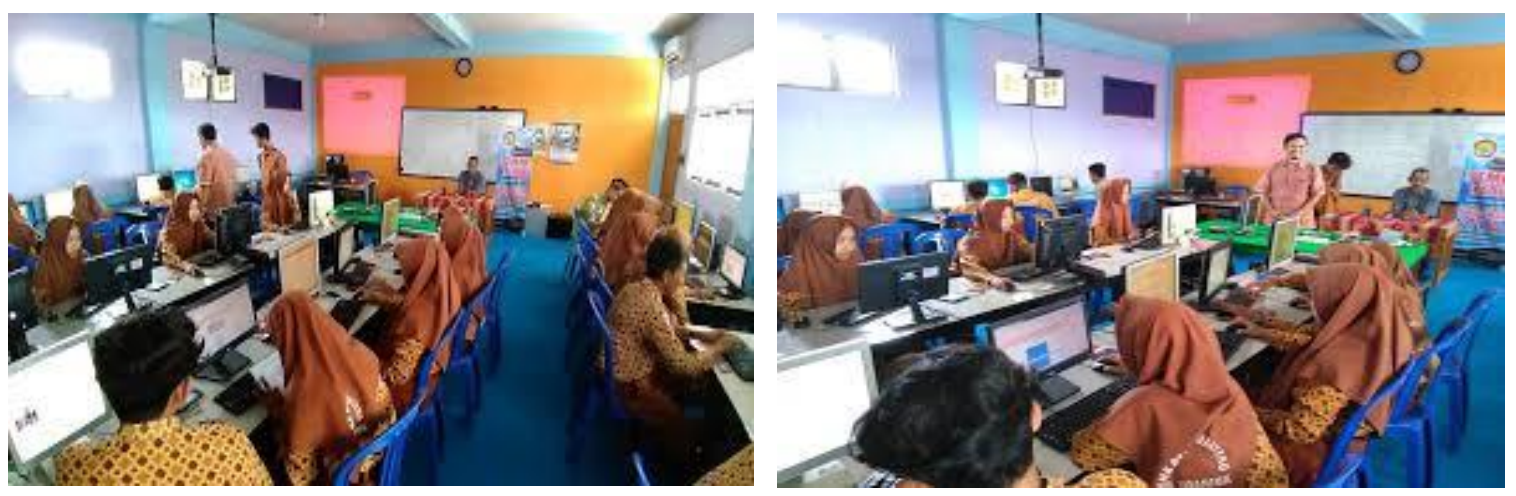

Gambar 5. Realisasi Kegiatan

Dengan adanya pengabdian ini akan memberikan edukasi dan pelatihan untuk guru-guru di lingkungan SMK AKP Galang sehinggga masalah di SMK AKP Galang dalam hal Kemampaun guru dalam memahami konsep pembelajaran yang berkembang saat ini, baik dengan konvensional ataupun modern, menjadikan guru-guru di AKP Galang aktif dan cakap dalam mengajar dengan menggunakan media komputer, dan membuat Modul bahan ajar yang dapat dijadikan sebagai acuan dalam mengembangkan media pembelajaran berbasis komputer dan sehingga hasil akhir dari pendampingan dan pelatihan ini guru-guru yang ada di SMK AKP Galang memiliki kemampuan untuk mengebangkan sendiri media pembelajaran berbasis komputer dengan menerapkan model CBI (Computer based Instruction), sehingga mudahnya siswa menyerap dan mengerti tentang materi yang dijelaskan dan meningkatkan kualitas pembelajaran di SMK AKP Galang, dan siswa/siswi di SMK AKP Galang menjadi siswa/siswi yang berprestasi dan menghasilkan lulusan-lulusan yang siap kerja dan berdaya guna tinggi bagi masyarakat sesuai dengan kompetensinya masing-masing. 


\section{Kesimpulan}

Pengabdian kepada masyrakat dengan judul "Pelatihan Tata Kelola Media Pembelajaran Multi Media Berbasis CBI (Computer Based Intruction) Untuk Meningkatkan Kualitas Pengajaran Guru di SMK AKP Galang" ini berjalan dengan baik, dimana jadwal, proses, dan pengerjaan berjalan dengan baik dan mitra pada pengabdian kepada masyrakat ini yaitu guru-guru pada SMK AKP Galang sangat antusias dalam mengikuti pelatihan dan pendampingan ini dan secara nyata meningkatkan skill dan pengetahuan guru-guru di SMK AKP Galang dalam membuat bahan ajar berbasis komputer dan mengebangkan sendiri media pembelajaran berbasis komputer dengan menerapkan model CBI (Computer based Instruction).

\section{Daftar Pustaka}

Bernard, M. (2015). Meningkatkan kemampuan komunikasi dan penalaran serta disposisi matematik siswa smk dengan pendekatan kontekstual melalui game adobe flash cs 4.0," infin. J.

Binanto, I. (2014). Perbandingan Metode Pengembangan Perangkat Lunak Multimedia Perbandingan Metode Pengembangan Perangkat Lunak Multimedia," Pros. Semin. RiTekTra 2013, 2014.

Budhi, G. S.. (2016). Analisis Sistem E-Commerce Pada Perusahan Jual-Beli Online LAZADA Indonesia. J. Electron. Informatics, Vocat. Educ.,.

Divayana, P. W. A. Suyasa, and N. Sugihartini. (2016). Pengembangan Media Pembelajaran Berbasis Web Untuk Matakuliah Kurikulum dan Pengajaran di Jurusan Pendidikan Teknik Informatika Universitas Pendidikan Ganesha," J. Nas. Pendidik. Tek. Inform.

Halawa, S. (2016). Perancangan Aplikasi Pembelajaran Topologi Jaringan Komputer Untuk Sekolah Menengah Kejuruan ( Smk ) Teknik Komputer Dan. JURIKOM (Jurnal Ris. Komputer).

Irfan, M. (2014). Implementasi Computer Based Instruction Model Instructional Games Pada Pembelajaran Interaktif Ed. Agustus.

Ramdhani, M. A.. (2014). Lingkungan Pendidikan dalam Implementasi Pendidikan Karakter," J. Pendidik. Univ. Garut,.

Nafiah, Y. N. et al. (2014). "Penerapan Model Problem Based Learning (PBL) pada Pembelajaran Hukum-Hukum Dasar Kimia Ditinjau dari Aktivitas dan Hasil Belajar Siswa Kelas X IPA SMA Negeri 2 Surakarta Tahun Pelajaran 2013/2014," J. Pendidik. Kim.

Uhyat. (2013). Metode Penelitian Pendidikan Pendekatan Kuantitaif, Kualitatif, dan R\&D Metod. Penelit. Pendidik. Pendekatan Kuantitaif, Kualitatif, dan R\&D. 